\title{
Best Bet Technology Package Development to Improve Sorghum Yields in Ethiopia Using the Decision Support System for Agro-Technology Transfer (DSSAT) Model
}

\author{
Fikadu Getachew, Gizachew Legesse, Girma Mamo \\ Ethiopian Institute of Agricultural Research (EIAR), Climate and Geospatial Research Directorate (CGRD), Addis Ababa, Ethiopia
}

Email address:

fikeget@gmail.com (F. Getachew)

\section{To cite this article:}

Fikadu Getachew, Gizachew Legesse, Girma Mamo. Best Bet Technology Package Development to Improve Sorghum Yields in Ethiopia Using the Decision Support System for Agro-Technology Transfer (DSSAT) Model. International Journal of Science, Technology and Society. Vol. 4, No. 1, 2016, pp. 7-13. doi: 10.11648/j.ijsts.20160401.12

\begin{abstract}
Sorghum is grown mainly in the semi-arid areas. In spite of the fact that there was observed high climate variability in the last few decades, rain fed sorghum [Sorghum bicolor (L.) Moench] production is still an important source of food and feed in the semiarid regions of Ethiopia. Although sorghum is realized as crop tolerant to water deficit, compared with other semiarid crops in Ethiopia, climate variability and change has been challenging its production and no intensive crop simulation modeling was done as it was desired. In this study the CERES-Sorghum Model of Decision Support System for Agro-Technology Transfer (DSSAT) has been tested over the north Rift Valley of Ethiopia. We have checked what would be the best combination of management options under research and farmers' practice conditions for each sites for the historical climatological periods (1980-2010) in which we have found that the model performs well in assimilating the real situation in our sentinel sites in both research and farmers' management practices. The potential grain yield from the DSSAT model would go up to $2.5 \mathrm{~T} / \mathrm{ha}$ under best scenario rainfall seasons without applying the developed technology package application (which we call it farmer's condition). The same sorghum variety has a potential yield of $6.2 \mathrm{~T} /$ ha if one can apply the recommended best bet technology packages (planting date, planting population, sowing data, fertilizer application rate and time) within the same season. Hereby we can assert that the application of the developed technology packages would make a difference of up to $3.7 \mathrm{~T} / \mathrm{ha}$ of grain sorghum yield under the same season. Even though applying the technology packages according to the prevailing seasons would significantly matter the expected grain yield, the worst possible grain yield lose would be minimized by applying the best bet technology packages that fits the specific season. Moreover, the selected sentinel sites were few, the result can be extrapolated using the calibrated crop simulation modeling to larger areas to develop strategic plans to improve grain yield of sorghum in Ethiopia.
\end{abstract}

Keywords: Crop Simulation, DSSAT, Sorghum, Technology Packages

\section{Introduction}

Sorghum is the fifth largest cereal crop in the world, after wheat, maize, rice and barley. It is cultivated in wide geographic areas in the Americas, Africa, Asia and the Pacific. It is the second major crop (after maize) across all agro-ecologies in Africa (Taylor, 2003). It is universally considered to have first been domesticated in North Africa, possibly in the Nile or Ethiopian regions around $1000 \mathrm{BC}$ (Kimber, 2000).

Sorghum is a singularly viable food grain crop for many food insecure people in sub-Saharan Africa (ICRISAT, 1994) because it is rather drought resistant among cereals and can withstand heat stress. Those parts of Africa, where sorghum is a significant arable crop are semi-arid and include the highlands of east Africa where bi-modal rainfall is intermittent. Sorghum is not only drought resistant but can also withstand periods of water-logging. The precise reasons for sorghum's environmental tolerance are not fully understood, and are undoubtedly multi-factorial (Doggett, 1988).

Over the past 25 years sorghum production has increased steadily in Africa, from 11.6 M T in 1976 to 20.9 M T in 2001, with most of this due to increased crop area not to improved rate of production. Average yields remain below $1 \mathrm{~T} /$ ha due to the applied subsistence farming practices; with low inputs (no 
inorganic fertilizer or pesticides) and traditional cultivar varieties (ICRISAT, 1996). Without mechanization and large-scale operations the consequent low yields leave no surplus sorghum, without which farmer's food security and processing industries cannot be created. However, where intensive agriculture is practiced with improved technology on varieties or hybrids, yields are much higher and comparable with other major cereals (Belton, 2004).

Integration of optimal technology packages and marketing could lift the livelihood of subsistence small-scale sorghum farmers and the adaptive capacity of the encompassing community.

The spread of cultivation areas into environmentally sensitive areas with great bio-diversity is highly damaging and unsustainable, and efforts must be aimed at intensifying sorghum agricultural practice in Ethiopia. Higher yields are essential, not only for rural food security but also for increasing population density and market commercialization.

To determine the best land-use practices for higher crop production, one must take into consideration the economic sustainability of the farmer as well as the ecological conditions of the environment. Among the tools that can be used to help solve some of these issues are computer-based biophysical simulation models. These crop simulation models have become more widely used in the past few decades by scientists to hypothesize ways to improve agricultural production under seasonal and daily weather variability. The models capture much of what we know about crop growth response to factors of temperature, solar radiation, rainfall, soil traits and crop management (Boote et al., 1998). Crop models have been used to evaluate management practices to improve yield for a given climatic region (Boote et al., 1996; Singh et al., 1994a, 1994b), to plan irrigation (Hook, 1994), and to evaluate climatic yield potential for different regions (Aggarwal and Kalra, 1994) or different costs (Alagarswamy et al., 2000).

Management practices such as sowing date, row spacing, sowing density, cultivar choice (both seasonal length and genetic traits), soil water availability, and fertilizer application are factors to enhance productivity. Variability of rainfall (onset, intensity, and cessation) as well as temperature, day length, and solar irradiance are important climatic factors that also impact management practices in a given region.

The models have been evaluated extensively and applied in agriculture to problems such as estimating the sensitivity of crop production to climate change (Williams et al., 1988; Alexandrov and Hoogenboom, 2000; Mall et al., 2004).

In this regard, the Ethiopian Institute of Agriculture Research (EIAR) has conducted research in sorghum technology development to improve productivity for small-holder farmers. Various technology applications have been documented, from place to place and time to time. From this we have distilled a combination of technologies into a 'package' via agricultural simulation models such as DSSAT $\mathrm{v} 4.5$, so that sorghum farmers can obtain useful advice to enhance their potential yield, regardless of the prevailing weather conditions.

Here we report on such a study to critically assess an optimal technology package; including stakeholder feedback on its practical application in the field.

\section{Study Area}

The dry land sorghum growing areas of Ethiopia can be characterized as areas receiving $350-800 \mathrm{~mm}$ of rainfall with a broad unimodal distribution. The rainfall has a coefficient of variability $>30 \%$ and displays multiple onsets and cessations (Hailu and Kidane, 1988). Sorghum in Ethiopia performs best with average temperatures 24 to $26^{\circ} \mathrm{C}$.

Our simulation modelling was conducted at three specific sites in the northern Rift Valley of Ethiopia (Figure 1) i.e. Fedis, Miesso and Kobo districts located at 42.03E,9.08N; $39.38 \mathrm{E}, 12.08 \mathrm{~N}$ and $40.46 \mathrm{E}, 9.14 \mathrm{~N}$ respectively. Their corresponding elevations are 1700,1470 and $1400 \mathrm{~m}$.

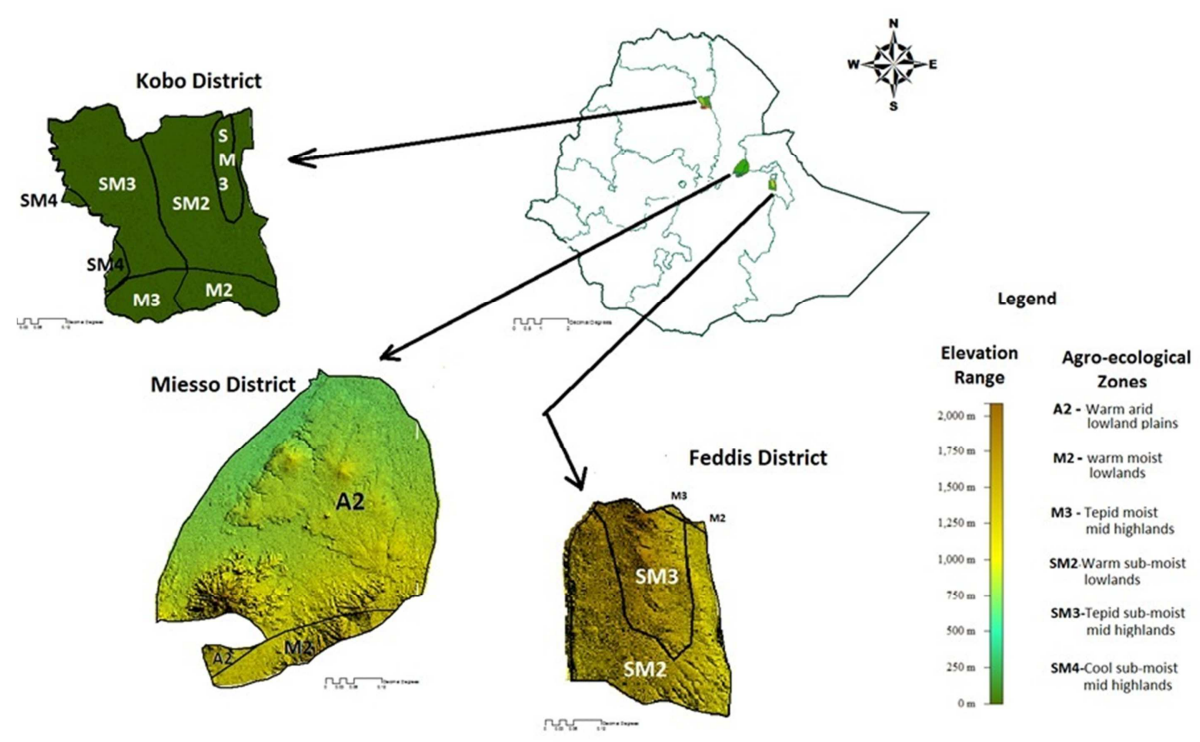

Figure 1. Selected sites for Sorghum modelling in northern Rift Valley of Ethiopia. 
The agro-ecological zones of the study sites fall under A2, M2, M3, SM2, SM3 and SM4 ${ }^{\mathrm{i}}$ with mean annual rainfall for Fedis, Meisso and Kobo of $614 \mathrm{~mm}, 765 \mathrm{~mm}$ and $691 \mathrm{~mm}$ respectively. The average monthly rainfall during the Sorghum growing period is shown in Table 1.

Table 1. Average monthly rainfall $(\mathrm{mm})$ for growing period at the three sites.

\begin{tabular}{lllll}
\hline Experiment Sites & June & July & August & September \\
\hline Fedis & 51.4 & 65.6 & 77.1 & 96 \\
Kobo & 36 & 137 & 200 & 65 \\
Miesso & 40.9 & 135.7 & 145.6 & 95 \\
\hline
\end{tabular}

\section{Data and Methodology}

The DSSAT v4.5 Crop growth model to hypothesize improvement in production of Sorghum in Ethiopia used 32 years of observed weather data. The following biophysical and management options were employed to arrive at the optimal technology package.

\subsection{Plot Design}

Three field experiments with the sorghum cultivar MEKO were conducted at Fedis, Kobo and Miesso sites under rain fed condition in 2010 and 2011. In all experiments, both research and farmer conditions were separately observed. Each plot had $50 \mathrm{~m}$ length x $50 \mathrm{~m}$ width, 44 rows and $0.75 \mathrm{~m}$ row spacing. Recommended crop management such as fertilizer rate application, sowing date, sowing depth, farm implement technologies and row spacing information was derived from earlier research works that has been conducted in the selected experiment sites (give peer-reviewed published reference).

\subsection{Soil and Weather Data}

As stated by Hailu and Kidane, 1988, sorghum can grow in different soil types from light sands to heavy clays if they are well drained. The $\mathrm{pH}$ should be above 5 but it performs best on deep, fertile sandy loams. Good yields are also possible on heavy but well drained soils. In fact, good fertility, drainage and optimum temperature are most important considerations in the successful culture of sorghum. This crop can tolerate considerable quantities of alkali or salts. Under rain fed conditions it performs well in the soils of high water retention capacity.

Major soil characteristics for the three sites namely; Cation exchange capacity, $\mathrm{pH}$, percent of total $\mathrm{N}$, percent of clay and silt, percent of organic carbon, Bulk density, hydraulic conductivity, root growth factors, percent of saturation, drained upper limit and lower limit, root growth factors and percent saturation were collected from each experiment site (Table 2). Monthly (from daily) weather data included solar radiation, maximum and minimum temperature and rainfall over the period 1973-2011 were obtained from meteorological stations at each site from the National Meteorology Agency of Ethiopia.

Table 2. Soil data used for this simulation just for the Miesso site which is one of the three study sites.

\begin{tabular}{|c|c|c|c|c|c|c|c|c|c|c|c|c|}
\hline $\begin{array}{l}\text { Profile } \\
\text { depth } \\
\mathrm{cm}\end{array}$ & $\begin{array}{l}\text { Lower } \\
\text { limit }\end{array}$ & $\begin{array}{l}\text { Drained } \\
\text { upper } \\
\text { limit }\end{array}$ & Saturation & $\begin{array}{l}\text { Root } \\
\text { growth } \\
\text { factor }\end{array}$ & $\begin{array}{l}\text { Hydraulic } \\
\text { conductivity }\end{array}$ & $\begin{array}{l}\text { Bulk } \\
\text { density } \\
\left(\mathrm{g} / \mathrm{cm}^{3}\right)\end{array}$ & $\begin{array}{l}\text { Organic } \\
\text { carbon \% }\end{array}$ & Clay \% & Silt \% & $\begin{array}{l}\text { Total } \\
\text { N\% }\end{array}$ & pH & $\begin{array}{l}\text { CEC } \\
\mathrm{cmol} / \mathrm{kg}\end{array}$ \\
\hline 10 & 0.341 & 0.483 & 0.683 & 1 & 0.06 & 0.74 & 1.5 & 58 & 28 & 0.06 & 7.8 & 48.9 \\
\hline 60 & 0.394 & 0.528 & 0.643 & 0.407 & 0.06 & 0.85 & 1.04 & 66 & 24 & 0.03 & 7.9 & 41.8 \\
\hline 90 & 0.368 & 0.506 & 0.651 & 0.223 & 0.06 & 0.83 & 1.04 & 62 & 26 & 0.01 & 7.9 & 41.8 \\
\hline 120 & 0.38 & 0.515 & 0.68 & 0.122 & 0.06 & 0.75 & 1.04 & 64 & 24 & 0.04 & 7.8 & 45.2 \\
\hline 180 & 0.404 & 0.533 & 0.618 & 0.037 & 0.06 & 0.92 & 1.04 & 68 & 20 & 0.04 & 7.8 & 39.2 \\
\hline
\end{tabular}

Table 3. The genetic coefficient data used for the simulation.

\begin{tabular}{|c|c|c|c|c|c|c|c|c|c|c|c|}
\hline Genetic coefficient & P1 & P2O & P2R & P5 & G1 & G2 & PHINT & P3 & P4 & $\mathbf{P 2}$ & PANTH \\
\hline Value & 294 & 12.5 & 30 & 399 & 2.9 & 6 & 49 & 152.5 & 81.5 & 102 & 617.5 \\
\hline
\end{tabular}

\subsection{Cultivar Selection}

The Sorghum cultivar used in this study is called MEKO. It is an early maturing variety which fits well to the dry semi-arid areas. The data required for genetic coefficient code definition are depicted in the Table 3.

\subsection{Planting Date and Fertilizer Application}

The planting time and fertilizer application (rate and timing) were analyzed under two scenario groups. The first group is under farmer condition and the second is under research condition. The planting time for the first group is under normal farmer condition and for the second was based on the analysis of mean rainfall data. The time of fertilizer application depended on the respective planting time and the application rate taken from previous research recommendations for the sites. The type of fertilizer used in this study is Diammonium Phosphate (DAP) (100 kg at the time of sowing) and Urea (50 $\mathrm{kg}$ when plants are knee height) (Table 4).

Table 4. Fertilizer application time and rate in all sites.

\begin{tabular}{|c|c|c|}
\hline \multirow{2}{*}{ Scenarios } & \multicolumn{2}{|c|}{ Fertilizer application time and rate } \\
\hline & DAP (100 Kg/Ha) & Urea at knee height $(50 \mathrm{~kg} / \mathrm{Ha})$ \\
\hline $\begin{array}{l}\text { Farmer } \\
\text { condition }\end{array}$ & None & None \\
\hline $\begin{array}{l}\text { Research } \\
\text { condition }\end{array}$ & 20-Jul & 20-Aug \\
\hline
\end{tabular}




\subsection{Tillage and Management Practices}

The farm implement technologies used for this simulation was classified as farmer and research based conditions. It is known that the level of depth that farm implements can be till have an influence on the productivity of crops. Accordingly the following type of farm implements and associated depth were taken in the simulation activity (Table 5 and Table 6).

Table 5. Tillage practice used for all implementation sites.

\begin{tabular}{lll}
\hline scenario & Tillage Practice & Depth (cm) \\
\hline Farmer condition & Cultivator field & 13 \\
Research condition & Cultivator, ridge till & 20 \\
\hline
\end{tabular}

Table 6. Management options used for the simulation of sorghum at Meisso.

\begin{tabular}{|c|c|c|c|c|c|c|c|c|c|}
\hline Scenarios & & $\begin{array}{l}\text { Planting } \\
\text { date }\end{array}$ & $\begin{array}{l}\text { Emergence } \\
\text { date }\end{array}$ & Planting & $\begin{array}{l}\text { Planting } \\
\text { distribution }\end{array}$ & $\begin{array}{l}\text { Plant population at } \\
\text { seedling (plant } / \mathrm{m} 2 \text { ) }\end{array}$ & $\begin{array}{l}\text { Plant population at } \\
\text { emergence } \\
\text { (plant/m2) }\end{array}$ & $\begin{array}{l}\text { Row } \\
\text { spacing } \\
\text { (cm) }\end{array}$ & $\begin{array}{l}\text { Planting } \\
\text { depth } \\
\text { (cm) }\end{array}$ \\
\hline \multirow{3}{*}{$\begin{array}{l}\text { Farmer } \\
\text { condition }\end{array}$} & Meisso & 25-Jun & 02-Jul & \multirow{3}{*}{ Dry } & \multirow{3}{*}{ Broadcast } & \multirow{3}{*}{9} & \multirow{3}{*}{9} & \multirow{3}{*}{50} & \multirow{3}{*}{3} \\
\hline & Kobo & 16-Jun & 24-Jun & & & & & & \\
\hline & Feddis & 26-Jun & 03-Jul & & & & & & \\
\hline \multirow{3}{*}{$\begin{array}{l}\text { Research } \\
\text { condition }\end{array}$} & Meisso & 20-Jul & 27-Jul & \multirow{3}{*}{ Dry } & \multirow{3}{*}{ Row } & \multirow{3}{*}{9} & \multirow{3}{*}{9} & \multirow{3}{*}{75} & \multirow{3}{*}{5} \\
\hline & Kobo & 12-Jun & 19-Jun & & & & & & \\
\hline & Feddis & 23-Jun & 30-Jun & & & & & & \\
\hline
\end{tabular}

\subsection{Planting Date}

Experimental results under dry land farming conditions have clearly revealed that dry or early sowing gives substantially higher yield compared to the traditional late planting after two or three effective rainfall (Hailu and Kidane, 1988). At Kobo dry sown sorghum (1-15 June) produced $2.3 \mathrm{~T} / \mathrm{ha}$, whereas, sowing after one, two and three effective rains gave 1.8, 1.4, 1.1 T/ha (Table 7). In the same way, in our simulation study we found that the date that gave the highest yield was June 15 when compared with late planting (July 20). However, an earlier planting date i.e. June 5 gave smaller yields than June 15. It would of course depend also on the fluctuations of rainfall during the growth period.

Table 7. Effect of planting date on grain yield of sorghum at Nazareth (Hailu and Kidane, 1988).

\begin{tabular}{lllll}
\hline \multirow{2}{*}{ Planting Dates } & \multicolumn{4}{l}{ Yield (T/ha) } \\
\cline { 2 - 5 } & $\mathbf{1 9 8 3}$ & $\mathbf{1 9 8 4}$ & $\mathbf{1 9 8 5}$ & Mean \\
\hline Dry planting & 3.455 & 0.611 & 2.746 & 2.268 \\
After one Effective rain & 2.466 & 0.618 & 2.506 & 1.771 \\
After two Effective rain & 1.53 & 0.463 & 2.383 & 1.407 \\
After three Effective rains* & 1.041 & 0.319 & 1.897 & 1.086 \\
\hline
\end{tabular}

\subsection{Agronomic Practices Adopted in This Study (Tied Ridge)}

Soil water stress is the 'bottleneck' of sorghum production in dry land areas. Several research activities were carried out to develop soil management practices, which store and conserve as much rainwater as possible by reducing runoff and improving infiltration and water storage in the soil profile. To this effect, tiled ridges have been found to be very efficient in storing the rain water and lead to substantial grain yield improvement for sorghum. According to Kidane and
Rezene (1989), a $45 \%$ increase of yield can be obtained for sorghum when compared to the traditional practice; depending also on soil type, slope, rainfall and cultivar (Table 8).

Table 8. Effect of soil conservation methods (tiled ridges) on grain yield of sorghum in the semi-arid areas of Ethiopia (Kobo and Melkassa) (Ridge height $=35 \mathrm{~cm}$, Ridge spacing $75 \mathrm{~cm}$, Ridges tied at $5 \mathrm{~m}$ interval, Numbers in Parenthesis are percentage of grain yield increase over control. (Source Kidane and Rezene 1989).

\begin{tabular}{llll}
\hline \multirow{2}{*}{ Soil conservation method } & \multicolumn{2}{l}{ Average grain yield T/ha } \\
\cline { 2 - 4 } & Kobo & Melkassa & Mean \\
\hline Flat planting (control) & 1.6 & 0.80 & 1.20 \\
Tiled Ridges planting in furrow & $2.9(81 \%)$ & $3.0(150 \%)$ & $2.95(145 \%)$ \\
\hline
\end{tabular}

\subsection{Crop Simulation Model}

CERES (Crop-Environment-Resource-Synthesis)-sorghum module in DSSAT v4.5 model is PC based crop simulation model which integrates all factors into a Cropping System Model (CSM) in a modular approach. The CSM uses one module for simulating soil water, nitrogen and carbon dynamics, while crop growth and development are simulated with the CERES, CROPGRO, CROPSIM and SUBSTOR modules. These components simulate the changes over time in the soil and plants that occur on a single land unit in response to weather and management practices.

\section{Results and Discussion}

\subsection{Validation of Model Performance}

The CERES-Sorghum Model of DSSAT has been tested over the selected sites in the northern Rift Valley of Ethiopia. The result shows that this model performs well under different 'packages' over two seasons. The statistical correlation is $97 \%$. (see figure 2 below) 


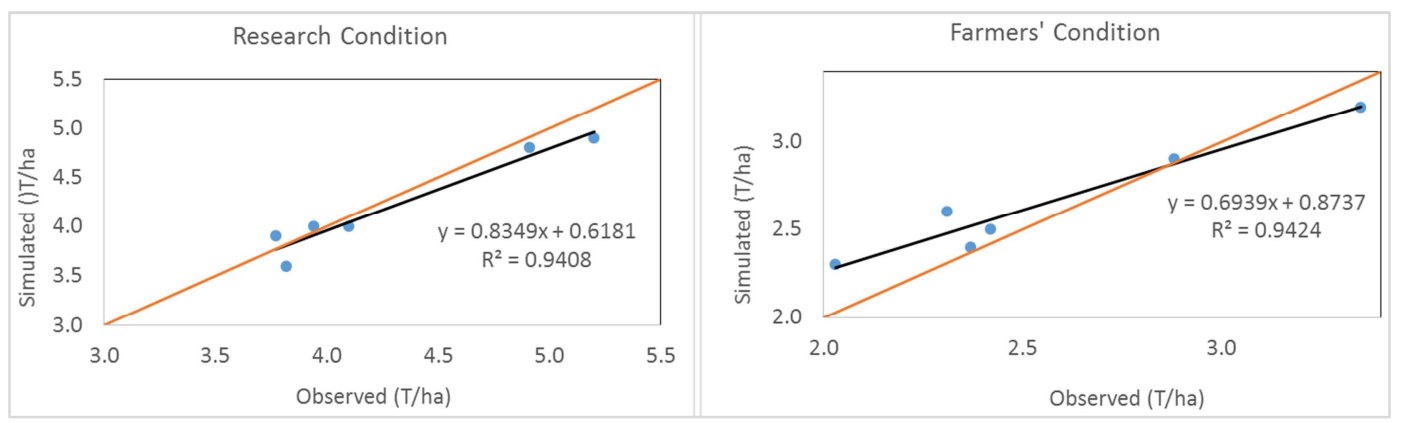

Figure 2. Validation of the CERES-Sorghum model under farmers and research condition in the study areas during the experment years.
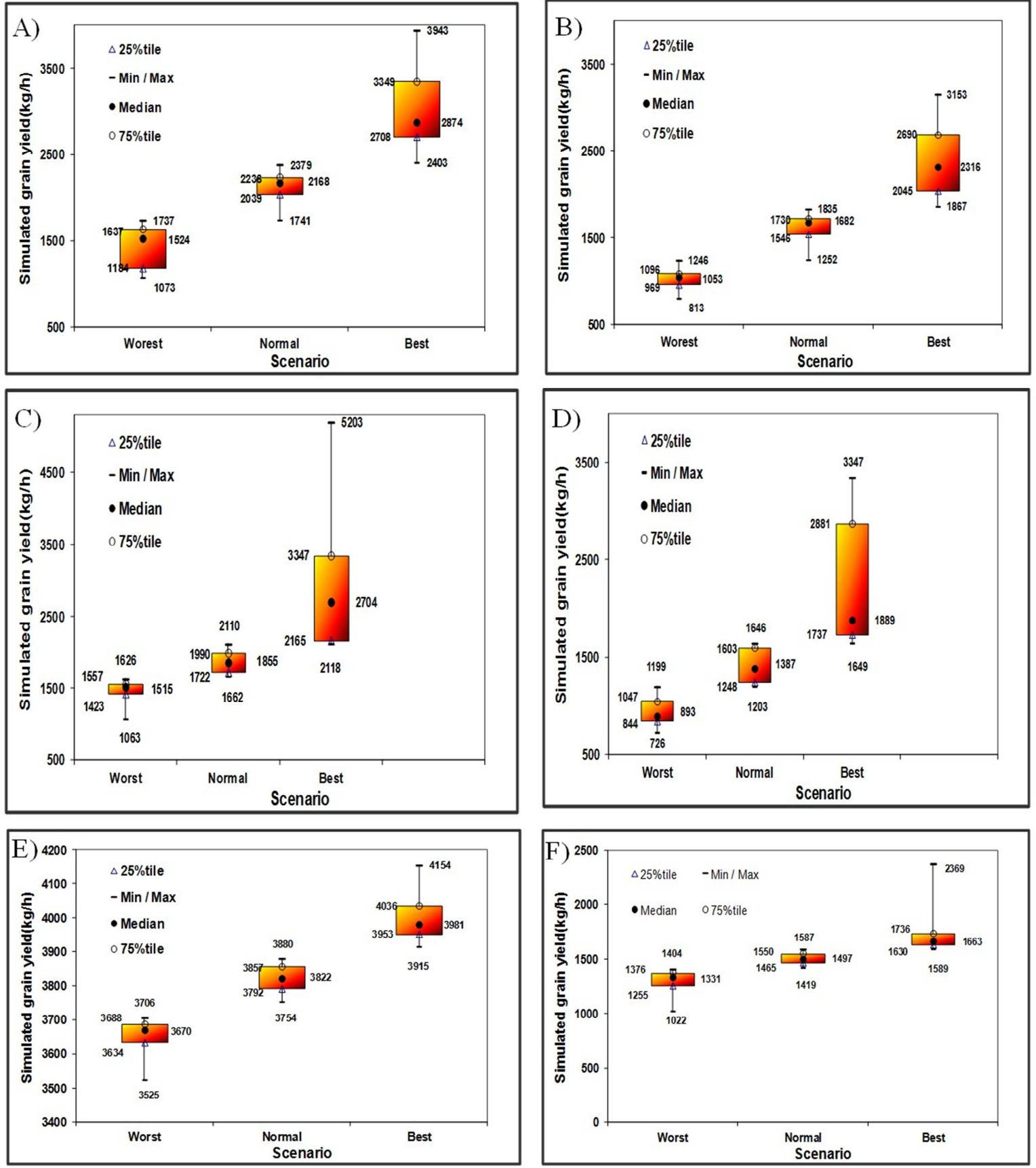

Figure 3. Box plot of potential grain yield of sorghum under research (Right) and farmers' (Left) management practice condition at Meisso (A and B), Kono (C and D), Feddis (E and F). 


\subsection{Simulated Sorghum Grain Yield}

In this study sorghum grain yield has been simulated depending on soil type and weather data. Mean simulated grain yield for these three sites was found to be comparable to the national grain yield of sorghum. The models realistically simulated the potential grain yield data. Values for plant parameters and soil parameters described in this paper offer user's reasonable inputs for simulating sorghum grain yields semi-arid areas of Ethiopia.

As it can be seen in figure 3 the mean sorghum grain yield under best scenarios would be as high as $2.3 \mathrm{~T} / \mathrm{h}$ at Meisso in which the same sorghum variety would be yield as high as 3.9 $\mathrm{T} / \mathrm{h}$ at Feddis by applying best bet technology packages. In other hands even if the worst scenario would happen the grain yield sorghum would be $1.06 \mathrm{~T} / \mathrm{h}$ at Kobo under best bet management options were applied. Meanwhile the situation would be worsen when we didn't apply those technologies and the yield would be get down to $0.72 \mathrm{~T} / \mathrm{h}$ at Kobo.

In our annual analysis, a management decision like crop and cultivar selection, planting density and spacing, planting date, timing, amount and types of fertilizer application and other options were evaluated to compare model output under expert research and subsistence farmer conditions. This allows the evaluation of management options (Tsuji et al., 1998). In view of this, the result depicted in box plot (Figure 3) revealed that the average yield of sorghum is 2.3 and $1.0 \mathrm{~T} /$ ha at Kobo under research and farmer condition, respectively. In the 75 percentile $>3.0 \mathrm{~T} / \mathrm{ha}$ is obtained under research condition while in farmer condition $1.2 \mathrm{~T} / \mathrm{ha}$. The figure also gives similar results for other percentiles, but clearly shows the research condition outperforms the farmer condition by a factor of about 3 .

\section{Conclusion and Recommendations}

The result of the validation suggests that the CERES-Sorghum model, as applied to the Meko cultivar was good at all experiment sites (i.e. Meisso, Kobo and Feddis). Moreover this is a suitable tool for optimizing management decisions to improve the potential grain yield of sorghum in Ethiopia.

The use of a crop simulation model incorporating biophysical factors can be used to explore possibility of options that help to efficiently utilize the existing resource of the area, while reducing the risk associated with climate. At the same time, it offers the possibility of saving time and resources required for the development of crop technologies. In this regard, DSSAT can provide possibility of different technological package for any combination of sowing date, varietal choice, soil type and crop management. Here we have given evidence that model is validated for local growing condition. Even though the simulation output is promising, it should be realized that the availability and quality of existing soil and weather data is a key element for DSSAT. Therefore, in order to verify crop outputs for different technological packages, it is recommended that data on genetic coefficient should be collected.

The experiment sites in this study, both for calibrating and validating the CERES-Sorghum model, were located in the low latitudes, which limits the use of the model for sites in other latitudes. Future research should therefore include studies to calibrate the model in sites other than in the low latitudes.

\section{Acknowledgements}

The authors would like to thank the Association for Strengthening Agricultural Research in East and Central Africa (ASARECA) for providing support to this study, and the Ethiopian Institute of Agricultural Research for providing full material and technical support. The National Metrological Service Agency is thanked for provision of weather data at the experiment sites. We thank the staff at Meisso, Feddis and Kobo Municipal Agricultural Department for their expertise for field implementation; and also we thank the Farmers for their part in the study.

\section{References}

[1] Aggaewal PK, and Kalra. N. (1994). Analyzing the limitations set by climatic factors, genotype, and water and nitrogen availability on productivity of wheat: II. Climatic potential yield and management strategies. Field Crops Res. 38: 93-103.

[2] Alagarswamy, G and Singh, P and Hoogenboom, G and Wani, S P and Pathak, P and Virmani, S M (2000) Evaluation and application of the CROPGRO-Soybean simulation model in a Vertic Inceptisol. Agricultural Systems, 63 (1).pp. 19-32. ISSN 0308-521X.

[3] Alexandrov, V. A., Hoogenboom, G., 2000. The impact of climate variability and change on crop yield in Bulgaria. Agricultural and Forest Meteorology, Volume 104, Pages 315-327. Pages 315-327.

[4] Belton, P. S., \& Taylor, J. R. (2004). Sorghum and millets: protein sources for Africa. Trends in Food Science \& Technology, 15(2), 94-98.

[5] Boote, K. J., Jones, J. W., \& Pickering, N. B. (1996). Potential uses and limitations of crop models. Agronomy Journal, 88(5), 704-716.

[6] Boote, K. J., Jones, J. W., Hoogenboom, G., \& Pickering, N. B. (1998). The CROPGRO model for grain legumes. In Understanding options for agricultural production (pp. 99-128). Springer Netherlands.

[7] Doggett, H. (1988). Sorghum. Harlow, Essex, England: Longman Scientific \& Technical.

[8] Gebre, H., \& Georgis, K. (1988). Sustaining crop Production in Ehe Semi-Arid areas of Ethiopia. Ethiopian Journal of Agricultural Sciences.

[9] Hook, J. E. (1994). Using crop models to plan water withdrawals for irrigation in drought years. Agricultural Systems, 45(3), 271-289. 
[10] International Crops Research Institute for the Semi-arid Tropics, Agriculture Organization of the United Nations. Commodities, \& Trade Division. (1996). The world sorghum and millet economies: facts, trends and outlook. Food \& Agriculture Org.

[11] International Crops Research Institute for the Semi-arid Tropics. (1994). ICRISAT now: sowing for the future. Patancheru, Andhra Pradesh, India: ICRISAT.

[12] Kidane, G. and R. Fesahays. 1989. Dry land research priorities to increase crop Productivity, pp.57-64. In Proceedings of 21st NCIC. Addis Ababa, Ethiopia.

[13] Kimber, C. T. (2000). Origins of domesticated sorghum and its early diffusion to India and China. Sorghum: Origin, history, technology, and production, 3-98.

[14] Mall, R. K., Lal, M., Bhatia, V. S., Rathore, L. S., \& Singh, R. (2004). Mitigating climate change impact on soybean productivity in India: a simulation study. Agricultural and forest meteorology, 121(1), 113-125.

[15] Parry, M. L., Carter, T. R., \& Konijn, N. T. (Eds.). (2013). The Impact of Climatic Variations on Agriculture: Volume 1: Assessment in Cool Temperate and Cold Regions. Springer Science \& Business Media.

$\mathrm{i} * \mathrm{~A} 2=$ Warm arid lowland plains, M2=warm moist lowlands, M3=Tepid mois mid highlands, SM2=Warm sub-moist lowlands, SM3=Tepid sub-moist mid highlands and SM4=cool submost high land
[16] Singh, P., Boote, K. J., \& Virmani, S. M. (1994). Evaluation of the groundnut model PNUTGRO for crop response to plant population and row spacing. Field Crops Research, 39(2), $163-170$.

[17] Singh, P., Boote, K. J., Rao, A. Y., Iruthayaraj, M. R., Sheikh, A. M., Hundal, S. S., ... \& Singh, P. (1994). Evaluation of the groundnut model PNUTGRO for crop response to water availability, sowing dates, and seasons. Field Crops Research, $39(2), 147-162$

[18] Taylor, J. R. N. (2003, April). Overview: Importance of sorghum in Africa. In Proceedings of AFRIPRO Workshop on the Proteins of Sorghum and Millets: Enhancing Nutritional and Functional Properties for Africa, Pretoria, South Africa (Vol. 9).

[19] Tsuji, G. Y., Hoogenboom, G., \& Thornton, P. K. (1998). Understanding options for agricultural production (Vol. 7). Springer Science \& Business Media.

[20] Williams, G. D. V., Fautley, R. A., Jones, K. H., Stewart, R. B., \& Wheaton, E. E. (1988). Estimating effects of climatic change on agriculture in Saskatchewan, Canada (pp. 219-379). Kluwer Academic Publishers. 